\title{
FOOD SAFETY AND EATING HABITS DURING PANDEMIC COVID-19 IN THE REPUBLIC OF SERBIA
}

Miloš Zrnićl, Nataša Kilibarda ${ }^{2}$, Ivana Brdar $^{3}$, Milan Vujićt ${ }^{4}$ Djordje Stojanović ${ }^{5}$

*Corresponding author: milos.zrnic@vhs.edu.rs

A R T I C L E I N F O
Original Article
Received: 20 January 2021
Accepted: 30 November 2021
doi: $10.5937 /$ ekoPolj2104895Z
UDC $351.778 .2:[616-$
036.22+578.834](497.11)

Keywords:

food, food safety, eating habits, COVID-19, Serbia.

JEL: L66, J28, Q18, I12, I10, I19

\begin{abstract}
A B S T R A C T
Food safety is of paramount importance at all times, especially in exceptional circumstances, such as pandemic COVID-19, given the fact that coronavirus is spreading rapidly and little is known about coronavirus. Protections have been strengthened in all fields, including food safety. In order to best protect ourselves and others, it's necessary to handle food properly, especially if children, pregnant women, the elderly and the ill ones are in the immediate vicinity. The paper will examine food safety and eating habits during pandemic COVID-19, with focus on recommended guidelines for safe food preparation, food storage, together with the prescribed measures of the Government of the Republic of Serbia.
\end{abstract}

(C) 2021 EA. All rights reserved.

\section{Introduction}

SARS-CoV-2 (coronavirus) was detected in December 2019, Wuhan market (China) in patients who had symptoms of viral pneumonia (Kaul, 2020; Naserghandi et al., 2020; Petrosillo et al., 2020). SARS-CoV-2 (coronavirus) virus causes COVID-19 disease,

1 Miloš Zrnić, Msc, Ph.D candidate at University Singidunum, Danijelova 32, Belgrade, Serbia, Lecturer at the Academy of Applied Studies - College of Hotel Management, Kneza Višeslava 70, Belgrade, Serbia, Phone: +381641155027, E-mail: milos.zrnic@vhs.edu.rs, ORCID ID (https://orcid.org/0000-0003-3454-6573).

2 Nataša Kilibarda, Ph.D., Assistant Professor at University Singidunum, Danijelova 32, Belgrade, Serbia, Phone: +38163785143, E-mail: nkilibarda@singidunum.ac.rs, ORCID ID (https://orcid.org/0000-0002-2967-3749).

3 Ivana Brdar, Ph.D., Assosiate Professor at University Singidunum, Danijelova 32, Belgrade, Serbia, Phone: +381652139815, E-mail: ibrdar@singidunum.ac.rs, ORCID ID (https:// orcid.org/0000-0002-7319-3822).

4 Milan Vujić, PhD., Lecturer at the Academy of Applied Studies - College of Hotel Management Belgrade, Kneza Višeslava 70, Belgrade, Serbia, Phone: +381698449003, E-mail: milan.vujic@vhs.edu.rs, ORCID ID (https://orcid.org/0000-0002-5870-0224).

5 Djordje Stojanović, Ph.D., Lecturer at the Academy of Applied Studies - College of Hotel Management, Kneza Višeslava 70, Belgrade, Serbia, Phone: +381641500318, E-mail: djordje.stojanovic@vhs.edu.rs, ORCID ID (https://orcid.org/0000-0001-9771-3389). 
transmitted by droplets during sneezing and coughing; it lands on an exterior accessible to humans, and by touching the eyes, mouth and nose with hand, humans can become infected (Borges do Nascimento et al., 2020). The original name of the coronavirus was 2019-nCoV, but it was later renamed SARS-CoV-2, as a result of the discovery of similarity of the virus with the SARS-CoV genome. (Chang et al., 2020; The Lancet Infectious Diseases, 2020). Symptoms include: fever, fatigue, high temperature, muscle aches, cough, loss of taste and smell. Approximately 1 in every 5 people affected by COVID-19, becomes seriously ill and develops difficulty breathing, and a fatal outcome is possible (World Health Organization, 2020). There are several hypotheses about the transmission of the coronavirus to humans, but none of these has been confirmed yet.

Based on limited initial transmission from human to human and clustering of cases at the Wuhan market (China), with the knowledge that coronavirus originates from animals as well as the link of SARS-CoV-2 to the coronavirus bat, there is a likelihood of zoonotic transmission in the first stage (Ahmadiara, E. 2020). Two-thirds out of 41 people, who previously visited Wuhan market and were infected with coronavirus - had close contact with meat and seafood products, which may indicate that the coronavirus can be transmitted from animals' products to humans (Guan et al., 2020; Harapan et al., 2020; Naserghandi et al., 2020).

Although research has shown that inactivation of the virus is happening faster in the area of high temperatures $\left(\geq 50^{\circ} \mathrm{C}\right)$, there are speculations that consumption of soup prepared by bats actually might be one of the probable causes of the spread of coronavirus (Lai et al., 2020; Sun et al., 2020). However, there is no confirmation that animals are the source of spreading COVID-19 (Katri, J. 2020). So far there is no evidence that coronavirus is spreading through food or food packaging (Food and Agriculture Organization of the United Nations \& World Health Organization, 2020).

There are already more than 85,172,095 reported cases and 1,844,153 deaths worldwide caused by coronavirus (World Health Organization, 2020), and these numbers are growing on daily basis. At the moment (Dec 2nd, 2020), the United Kingdom is the first and only country to approve coronavirus vaccine (www.gov.uk). The Pfizer/BioNTech is the first approved vaccine against COVID-19, developed in 10 months, which is considered a fairly short period, taking into account that the usual drug development and approval procedure takes 10 years.

\section{Food safety in the Republic of Serbia}

First case of infection SARS-CoV-2 (coronavirus) in the Republic of Serbia was recorded on March 6, 2020. A few days later, on March 11, 2020, the WHO declared a pandemic. In severe cases, symptoms such as: pneumonia, acute shortness of breath syndrome, sepsis and septic shock occur, can cause patient's death. People suffering from chronic diseases seem to be more susceptible to severe forms of the disease.

In 2020, 337.923 COVID-19 cases have been registered in the Republic of Serbia, with number of deaths reaching 3.211. At the very beginning of the pandemic, there were high concerns 
about food safety and food handling, with special emphasis on the right way to prepare a safe meal. In order to address these concerns, the Government prepared and strongly advised following special guidelines, along with good manufacturing practice (www.vet.minpolj.gov.rs):

- The raw material from which food is prepared must come from healthy animals

- Food must meet microbiological criteria (hygiene and safety)

- During food preparation, water that is used must be of drinking water quality

- Raw and prepared food should be stored at the prescribed temperatures.

It is the right of all consumers to expect safe, clean and quality food. Thus, safe food handling should be applied to prevent hazards. Food safety can be ensured by following \& applying HACCP principles (Hazard Analysis Critical Control Point), (Kilibarda, 2019), together with GHP (Good hygiene practices), and Good manufacturing practices. Good hygiene practices are set of prerequisite requirements created with aim to prevent food contamination. Hygiene requirement can be applied both to households and hospitality sector including: personal cleanliness; training programs; maintenance; cleaning; waste management; environment hygiene; pest control; hygienic production of food sources; transport; food storage; lightning (European Commission, 2004). Good manufacturing practice (GMP) are set of recommendations from authority agencies with aim to meets fundamental food quality requirements. Importance of GMP and its application in the food business sector refers to food quality control at all times. HACCP system helps to lookout for potential hazards in the food chain, and to effectively assess hazard's location, the hazard level of threat for food safety, but also to control or reduce hazards to the appropriate level (Borovcanin \& Kilibarda, 2020).

To stay competent and sustainable in today's modern business world, hospitality companies need to follow latest procedures by HACCP principles, GMP and GHP. Good manufacturing practices provide guidance for manufacturing, testing and quality insurance in order to ensure that a food is safe for human consumption. Food safety is major concern for customers and hospitality sector, but these concerns can be reduced by following the principles prescribed by health authorities, and this way food safety value can be increased in hospitality industry immensely (Manning, 2018). Lack of good manufacturing practice, could potentially lead to food contamination (Rossi et al., 2018). According to Serbian Food \& Safety Law 17/2019 (Serbia, 2019), all food and beverages business are obligated to set up a safe structure of food production, together with the principles of HACCP.

Additional security measures (in correlation to COVID-19 infection) of public health authorities for food producers / owners of catering facilities - restaurants, hotels, motels, caffes, pastry shops, in the Republic of Serbia, include:

- Staff with COVID-19 symptoms should not work, alone or with colleagues

- Careful handling of raw meat, milk or animal organs, avoidance of uncooked food contamination, cross-contamination and consumption of raw or uncooked animal products 
- Regular cleaning and disinfection of dishes, washing clothes, equipment, work surfaces, as well as all rooms (since coronavirus can be alive for 72 hours on facilities such as packaging material, food stations, polyvinyl chloride surfaces, cups, stainless steel, plastic products)

- Limiting the number of people in the kitchen at any time - keeping safe distance

- Limiting the number of guests who can come to the restaurant

- Using glows, wearing masks, using hand sanitizers at all times

- Adherence to the rules and guidelines of WHO/other competent institutions.

Household protection measures include compliance with the following four food safety steps, which are important at any times (www.foodsafety.gov):

1. Food cleaning

2. Proper food separation

3. Cooking food at appropriate temperatures

4. Food refrigeration.

A significant number of cases of foodborne diseases in the household are reported by the European Food Safety Authority (EFSA, 2018), followed by cases in food-service sector. In the last ten years, in Great Britain, United States of America, Australia and New Zealand, close to $90 \%$ foodborne diseases are related to food being prepared or consumed in the household (Baltic et al., 2013). Despite the fact that most consumers assume that foodborne diseases occur when consuming food outdoor (restaurants, bars, hotels), studies show that most food poisoning occurs when preparing food at home (Baltic et al., 2013). It has been found that $25 \%$ of cases of foodborne illness recorded in the household are related to inadequate food handling and storage (Baltic et al., 2013). Food experts agree with the above-mentioned fact that a number of foodborne illnesses occur as a result of improper food handling and preparation by the customer, although customers themselves are not aware of this fact (Vorsfold \& Griffith, 1997). To avoid and prevent foodborne illness in the household, public health authorities must share information on how food is handled, including proper storage and thermal processing of food. It is best to thermally process food by cooking, heating to a temperature of $149^{\circ} \mathrm{F}\left(65^{\circ} \mathrm{C}\right)$, for at least three minutes. As COVID-19 is a global issue, it is clear that food safety is under scrutiny on a global scale. According to Jingjing et al., (Jingjing, Y., Yonglong L., Xianghui, C \& Haotian C, 2020) some of the proposals for improving global food safety are:

1. Raising awareness of the dangers of wildlife consumption

2. Strengthening legislation on food and wildlife trafficking

3. Improving food safety standards

4. Establishment of market supervision mechanism. 


\section{Materials and methods}

The research is focused on opinions of the respondents regarding food safety, as well as their eating habits. The paper research uses the online survey method and in person interview. Data collection was conducted in the period September 1, 2020 - November 1,2020 . The sample of the study consists of 130 respondents, aged 18 to $60+$ years. The questions include demographic characteristics, followed by questions about food safety opinions and attitudes, and finally questions about eating habits during a pandemic. Minor part of the data was collected in person during the mentioned period, while the other part was collected through an online survey. The survey was explicitly designed for this research. SPSS (SPSS Statistics 22) was used to analyze all collected responses. Descriptive statistical analysis was successfully used to illustrate the dietary habits of the respondents, taking into account the opinions of the respondents regarding food safety. Pearson correlation coefficient was used to measure correlation between two variables - respondents' age and their awareness on food safety. The Likert scale was also used to evaluate the answers, where 1 means "I completely disagree", while 5 stays for "I completely agree".

\section{Results}

Demographic characteristics of the respondents indicate larger number of women (65\%) compared to the male population (35\%). Significant number of respondents has faculty degree $(41 \%)$, followed by master degree $(28 \%)$, high school $(20 \%)$, college degree $(6 \%)$ and $\mathrm{PhD}(5 \%)$. Further demographic details are presented in Table 1.

Table 1. Demographic characteristic

\begin{tabular}{|c|c|c|c|}
\hline Section & Status & Respondent number & \% \\
\hline Gender & Men & 46 & 35 \\
\hline & Woman & 84 & 65 \\
\hline Age & $18-25$ & 22 & 17 \\
\hline & $26-40$ & 80 & 61 \\
\hline & $41-50$ & 14 & 11 \\
\hline & $51-60$ & 8 & 6 \\
\hline & $61+$ & 6 & 20 \\
\hline Education & High school & 26 & 6 \\
\hline & College & 8 & 41 \\
\hline & Faculty & 54 & 28 \\
\hline & Master degree & 36 & 5 \\
\hline & Phd Degree & 6 & 2 \\
\hline Respondent status & Employed & 100 & 12 \\
\hline & Unemployed & 2 & 6 \\
\hline & Student & 16 & 3 \\
\hline & Entrepreneur & 8 & 47 \\
\hline
\end{tabular}

Source: Authors' findings 
In addition to this, the majority of respondents live in Belgrade (75\%), Novi Sad (15\%), Nis $(6 \%)$, while $4 \%$ of research data were collected in person during the respondents' visit to Belgrade. Of all respondents, $22 \%$ people work in the food and beverage sector. Along with demographic inquiries, the research contains three sets of questions, presented in Table 2. The first set of questions is related to food safety, and the other two are related to eating habits during COVID-19.

Table 2. Sets of questions for research

\begin{tabular}{|l|l|}
\hline 1. & $\begin{array}{l}\text { FOOD SAFETY AND GOOD HYGIENE PRACTICE } \\
\text { Aim: To determine if pandemic influenced awareness on food safety and daily habits } \\
\text { related to food hygiene. }\end{array}$ \\
\hline 1.1. & How long do you wash your hands after the outbreak of COVID-19? \\
\hline 1.2. & Did you disinfect each food after purchase, before COVID-19? \\
\hline 1.3. & Do you disinfect each food after purchase, during COVID-19? \\
\hline 1.4. & If you disinfected food during the COVID-19, what did you use for this purpose? \\
\hline 1.5. & After COVID-19 outbreak, how would you rate the importance of hand hygiene? \\
\hline 1.6. & How much COVID-19 affected your awareness of the importance of food safety? \\
\hline 2. & $\begin{array}{l}\text { TYPE OF FOOD IN DAILY NUTRITION } \\
\text { Aim: To determine whether pandemic affected type of food that is consumed on daily } \\
\text { basis, given that meat was initially in correlation with COVID-19. }\end{array}$ \\
\hline 2.1. & Do you consume more vegetables after the COVID-19 outbreak? \\
\hline 2.2. & $\begin{array}{l}\text { Has COVID-19 affected the increased intake of fruits and fruit products in your } \\
\text { daily nutrition? }\end{array}$ \\
\hline 2.3. & Do you consume more sweets during the COVID-19 pandemic? \\
\hline 2.4. & How much has COVID-19 increased your alcohol consumption? \\
\hline 2.5. & Have you stopped consuming some foods during COVID-19? \\
\hline 3.1. & $\begin{array}{l}\text { FOOD PREPARATION PROCESS } \\
\text { Aim: To determine if food preparation process has undergone changes due to pandemic } \\
\text { and local measures that followed it. }\end{array}$ \\
\hline 3.3. & How much has COVID-19 affected your frequency of food preparation at home? \\
\hline of food preparation?
\end{tabular}

Source: Authors' findings

Forasmuch demographic characteristic of respondents and the subject matter, following research hypothesis are tested:

H1: Awareness on food safety during COVID-19 is not related to age.

H2: Changes in eating habits during the COVID-19 do not depend on gender. 


\section{Analysis of respondents' opinion on food safety}

Handwashing was emphasised as an important precautionery measure, with regards not only to food safety, but safety and health in general (WHO, 2019). Also, Centers for Disease Control and Prevention (CDC) recommends washing hands for $20+$ seconds with water and soup, or if water or soup is not available, a hand sanitizer with $60 \%$ of alcohol can be used as a substitude (CDC, 2020). Our research showed that $15 \%$ of respondents wash hands for $20+$ seconds, $55 \%$ of respondents wash hands beetwen 10 20 seconds, while $30 \%$ wash their hands around 10 seconds. Unlike other age groups, only respondents age 18-25 and 26-40 wash hands $20+$ seconds or longer.

On the other hand, Carl et al. (2013) in their study, claim that average time among respondents to wash their hands is less than 7 seconds. According to study by Guzek et al (2020) conducted in Poland, among 384 respondents, reported handwashing time for man: less than 5 seconds $(0.4 \%), 5-10$ seconds (3.8\%), 11-20 seconds (11.9\%), $21-40$ seconds $(65.8 \%), 40+$ seconds $(10.1 \%)$, time doens`t mater $(4.5 \%)$, and „I don't know" (3.4\%); and female: less than 5 seconds (0.3\%), 5-10 seconds (1.9\%), 11-20 seconds (10.1\%), 21-40 seconds (74.2\%), 40+ seconds (9.5\%), time doesn't matter (1.3\%), and „I don`t know“ (2.5\%). According to Olaimat et al survay (2020), 66.8\% of respondents wash their hands for less that 20 seconds.

These results may indicate that during the pandemic period, respondents wash their hands longer than before the pandemic. To effectively prevent the spread of germs from hands, it is recommended to wash hands for more than 20 seconds (WHO, 2019).

When it comes to food disinfection, $72 \%$ people included in the research have never disinfected all the food/groceries before pandemic, $17 \%$ did it at times, while $11 \%$ did it all the time. After COVID-19 outbreak, 35\% of respondents claimed that they still don't disinfect all food after purchase, 37\% disinfect food sometimes, while $28 \%$ of respondents do so constantly. These results indicate that our respondents pay less attention on food disinfection, before the pandemic. The European Food Safety Authority (EFSA, 2020) advocates that food disinfection can be avoided if certain prerequiste measures are taken: (1) handwasing (20+ seconds; water+soup) before and after food purchace, (2) ordering food online, (3) touch only the food that you intend to buy. On the other side, the Brazilian Association of Clinical Nutrition (2020) has advised proper hygiene practices whenever possible. The same assosiation suggest the use of water in combintion with soup or alcohol (70\%) when handiling groceries.

According to Food and Agriculture Organization of the United Nations (FAO, 2020), 5 recommended steps for food safety are: (1) separation heat-treated food from fresh; (2) cook food at the right temperature; (3) store food at the right temperature; (4) use tap water when cooking; (5) maintain food hygiene (cleanness). The interesting result is that all respondents who do not work in hospitality $(100 \%)$, answered that during pandemic they started to disinfect groceries prior to preparation, while before pandemic $76 \%$ of them never did it, $16 \%$ did it occasionally and $8 \%$ did it on a regular basis. Respondents working in hospitality sector answered in the following manner: before pandemic, $57 \%$ 
never disinfected groceries, $21 \%$ did it at times, and $22 \%$ did it regularly, while after pandemic $42 \%$ still don't do it, $36 \%$ do it occasionally and $32 \%$ do it all the time. With respect to this result, it is obvious that pandemic has had a strong impact on awareness about food safety among the general population, while hospitality workers have not raised their awareness to a large degree, yet they rather kept their old habits. When disinfecting groceries, more than half of respondents $(63 \%)$ used water only or water combined with soda, while the rest used alcohol $(25 \%)$, chemical $(7 \%)$ or other products $(5 \%)$. From these answeres we can see that water is still leading liquid used to disinfecting food, followed by alcohol and chemicals. It is not suprise that alcohol is on the second place; usage of alcohol-based sanitizers has increased compared to other liquids (Gold \& Avva, 2018). However, disinfection methods should be used wisely, as most people may possibly use inappropriate disinfectants, believing that all disinfectants on the market can eliminate coronavirus (Quevedo et al., 2020). Further detailed results according to gender are given in the Figure 1.

Figure 1. Food disinfecting habits - gender differences

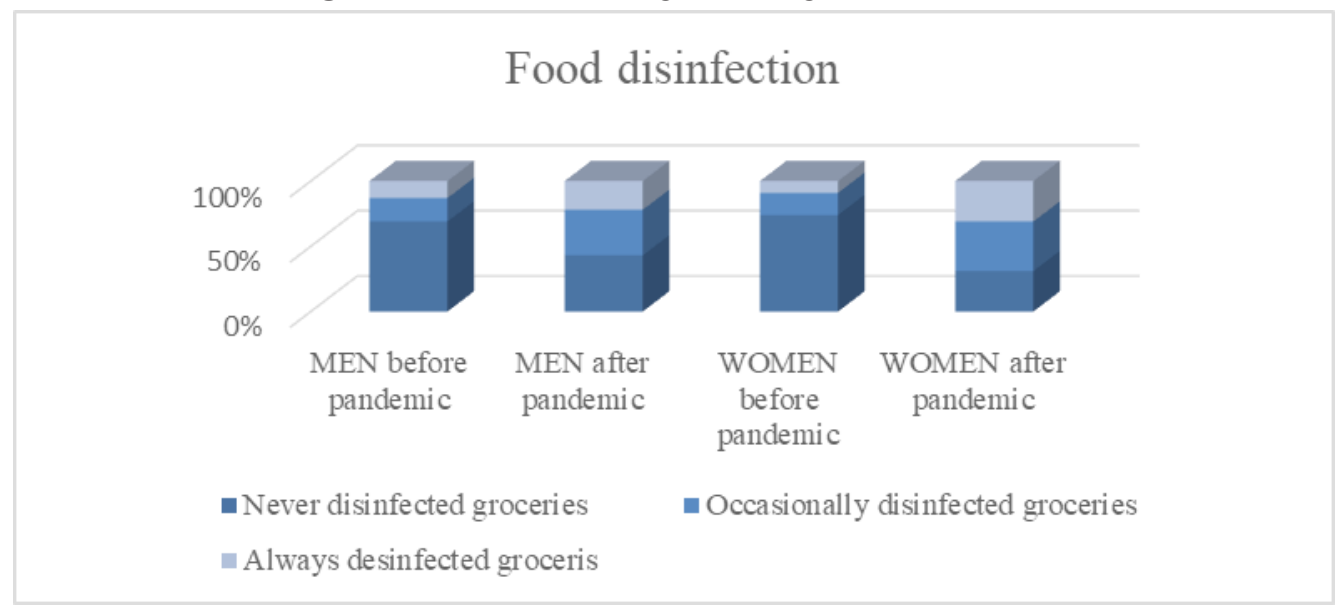

Source: Authors' findings

Althought it is clear that pandemic affected people's awareness on food safety, average respondents' answer to question 'How much COVID-19 affected your awareness of the importance of food safety? " was 2.96 out of 5 on Likert scale. Men' rate 3.17 was to a certain extent higher than women' 2.85. Study in Qatar by Hassen, El Bilali \& S Allahyari, (2020) reported that education level had effect on food safety awareness, food delivery, changes in behaviors affected by pandemic among respondents. Quao et al. (2012) argues that knowledge of food safety laws among consumers is not impressive at all. In support of this claim, Yin and Han (2014) claim that people who are prone to panic are people with lower education level. In China, study by Shi, Xiang and Zhang (2020), mention that pandemic certainly affected people's awareness of behavior and the importance of food safety. 
The same survey highlights that with improvement of food safety knowledge, customer behavior should change as well. Food safety awareness among people of different age, in this research, ranges from 2.81 to 3.33 .

In line with H1, which states that awareness on food safety during COVID-19 is not related to age, Pearson correlation coefficient was used to measure correlation between two variables (Table 3 ).

The first one presents age of respondents (initial value is used), and the second one presents results on Likert scale.

Table 3. Correlation between age and food safety awareness

\begin{tabular}{|c|c|c|}
\hline RESPONDENTS' AGE & $\begin{array}{c}\text { AGE } \\
\text { (Variable 1) }\end{array}$ & $\begin{array}{c}\text { VALUE (Variable 2) } \\
\text { Food Safety Awareness }\end{array}$ \\
\hline $18-25$ & 18 & 2.81 \\
\hline $26-40$ & 26 & 3.05 \\
\hline $41-50$ & 41 & 3.29 \\
\hline $51-60$ & 51 & 1.75 \\
\hline $61+$ & 61 & 3.33 \\
\hline
\end{tabular}

Source: Authors' findings

According to numerical variables given, Pearson correlation coefficient (r), is -0,08. Negative correlation generally indicates that two variables do not increase together. As $0<|\mathrm{r}|<0.10$ (absolute value), correlation between these two values is insignificant.

In other words, increasing the age of the respondents does not lead to increased awareness on food safety. On the other hand, Jay et al (1999), in their Australian study, report that awareness/knowledge of food safety among respondents increased with the age. According Shi, Xiang and Zhang (2020), respondents between 18-25 showed really low knowledge on food safety compared to elderly respondents $\leq 50$ where score was high. Moreover, in the same study, the level of education appears to be non-linear related to "customer knowledge on food safety".

\section{Analysis of respondents' opinion on eating habits}

In addition to food safety analysis, this paper also presents results on eating habits before and during the COVID-19 pandemic, via descriptive statistics. Information related to eating habits of both genders are given below (Table 4). 
Table 4. Eating habits of female and male respondents

\begin{tabular}{|c|c|c|c|c|c|}
\hline & QUESTIONS ON EATING HABITS & MEN & $(\%)$ & WOMEN & $(\%)$ \\
\hline & & YES & $\mathrm{NO}$ & YES & $\mathrm{NO}$ \\
\hline 1. & $\begin{array}{l}\text { Do you consume more foods of plant origin } \\
\text { after the COVID-19 outbreak? }\end{array}$ & $9 \%$ & $91 \%$ & $10 \%$ & $90 \%$ \\
\hline 2. & $\begin{array}{l}\text { Has COVID-19 affected the increased } \\
\text { intake of fruits and fruit products in your } \\
\text { daily nutrition? }\end{array}$ & $35 \%$ & $65 \%$ & $21 \%$ & $79 \%$ \\
\hline 3. & $\begin{array}{l}\text { Do you consume more sweets during the } \\
\text { COVID-19 pandemic? }\end{array}$ & $17 \%$ & $83 \%$ & $31 \%$ & $69 \%$ \\
\hline 4. & $\begin{array}{l}\text { As a consequence of the COVID-19 } \\
\text { pandemic, have you adopted new ways / } \\
\text { methods of food preparation? }\end{array}$ & $13 \%$ & $87 \%$ & $29 \%$ & $71 \%$ \\
\hline
\end{tabular}

Source: Authors' findings

According to the study, subjects used food of animal origin in their diet very frequently before the outbreak of COVID-19. This is confirmed by very high value (4.17) on scale from 1 to 5, where 1 stands for „I don't eat meat" and 5 stands for , I eat meat every day"; men' value was a bit higher (4.22) in comparison to women' (4.14).

A recent study published in November 2020, states that meat (bats and pangolins) could be associated with the coronavirus (Duda-Chodak, Lukasiewicz, Zięć, Florkiewicz, \& Filipiak-Florkiewicz, 2020). Based on fear that certain meat could be related to virus, there is a possibility of reduced meat consumption in the future (FAO, 2020). In our study, only $8 \%$ of respondents started using more vegetables than meat in their diet during the pandemic. Further research reports that more than a quarter of total number of respondents $(26 \%)$ have increased daily fruit intake in comparion to pre-pandemic period, while the same percentage $(26 \%)$ started to eat more sweets in examined period. Another study in Qatar by Al Thani (2018), highlighted that 83\% of the people consume less vegetables, legumes and fruits, $70 \%$ of the respondents are overweight, and lastly $47 \%$ of the respondents noted constant fast-food intake. According to Chenarides et al. (2020), from the outset of COVID-19 pandemic, food consumptions among respondents $(60 \%)$, remained almost the same, 13\% stated "consume less food", $21 \%$ said "they consumed more food", the rest $6 \%$ stated "healthier nourishment". Hassen, El Bilali \& S Allahyari (2020), in their study highlighted increased consumption of vegetables and fruits (32.4\%), as well as consumptions of "healthy foods" 32.3\%. However, as a result of these data, increased vegetable intake among subjects may have been related to the current period of the pandemic.

Further, when asked about alcohol consumption and the impact on this habit, the average value on Likert scale was quite low, 1.85 out of 5. Women had a bit higher average value, 1.93 compared to men' value 1.7 meaning that they increased alcohol consumption more than men. Nielsen Company Survey conducted in March 2020 in the USA, share interesting results, alcohol orders online rose by $240 \%$ (Micallief, 2020). Also, an increased number of aggressive behaviors have been reported in the United 
States in connection with alcohol abuse (Aarø et al., 2019). During other catastrophic events caused by man or nature such as war or hurricane, it's been reported that people drank more than usual (Jernigan, 2020). Study in Poland by Chodkiewicz et al (2020), during pandemic period noted that nearly $73 \%$ of the respondents consume alcohol, then cigars $(25 \%)$, followed by some sort of drugs ( $4 \%)$.

From further data in our study, we see that women adopted new methods of food preparation, to larger extent than men, which might be the positive side of pandemic. Although, restaurants only worked part-time, as one of the Government mesaures to reduce the spread of the virus, it did not greatly affect the frequency of food preparation at home. With regard to it, average rate on Likert scale was 3.03, women' 3.05, and men' values 3 .

It is evident that eating habits changed to certain extent, and when asked explicitly ", How much did the outbreak of the COVID-19 pandemic affect your eating habits? " answers differ, from 1 to 5 on Likert scale, with 2.55 average value; women average value was 2.51 and men' was 2.61. The interesting fact is that during pandemic, male respondents have mostly increased fruit intake, while female respondents have started to consume far more sweats. These results do not come as surprise, Chenarides et al. (2020) in their study reports that from the beginning of pandemic, snack (sweet/ salty) intake increased $41.9 \%$. Another study in Italy on "impact of COVID-19 on food consumption", highlights those respondents ate more than usual (46.1\%), while $19.5 \%$ said they increased body weight (Scarmozzino and Visioli, 2020). Moreover, in the same study increased consumption of sweets (to be specific - ice cream 42.2\%) and snacks $23.5 \%$ was reported. Negative feelings caused by lockdown, might lead to overeating, usually food containing sugar, salt and fats (Moynihan et al., 2015; Y1lmaz and Gökmen, 2020). However, opposite results from Hassen, El Bilali \& S Allahyari research (2020), claim that respondents reduced unhealthy foods (snacks), and $28.7 \%$ respondents noted decreased intake of sweets.

During lockdown, when most coffee shops and restaurants are closed, most of the people spend their time at home preparing meals (Hassen, El Bilali \& S Allahyari, 2020). Research conducted in the USA by Food Industry Association noted that $41 \%$ of American citizen spend more time preparing food, $27 \%$ of respondents have meal plans, and 20\% ate new foods since the outbreak of the COVID-19 pandemic. In the current circumstances, people may find more time for home activities (Hassen, El Bilali \& S Allahyari, 2020).

In Tunisia, Jribi et al. (2020) reported better customer behavior when shopping food, during COVID-19 crisis, as well as food waste improvements. This current reported behavior is probably more in connection with economic situation (Jribi et al., 2020). Another interesting survey in Italy by Di Renzo et al. (2020), states that during COVID-19 period, $55 \%$ of the respondents cook $30 \%$ more unused food at home. According to Hassen, El Bilali \& S Allahyari (2020) survey in Qatar, respondents (44.81\%) also indicate less food wastage since the COVID-19 pandemic. 


\section{Conclusion}

The COVID-19 pandemic has further raised awareness of the importance of food safety globally and led to consideration of new measures aimed at protecting people from similar pandemics in the future. In these challenging times, with many unknowns about the new form of the virus, the good news is that there is no evidence yet, that food is a channel for transmission of the coronavirus.

Given the emerging situation, the good hygiene practice, wearing mask and social distance is still considered the best practice to prevent COVID-19 infection. More than ever, special attention is must to food safety, from choosing food, cleaning and disinfecting in proper manner, to right preparation and storage, including application of HACCP and strong adherence to the WHO recommendations and other prescribed measures of competent institutions on global and national level (Government of the Republic of Serbia). The limitation of the research itself, in order to obtain more statistical differences among the respondents, refers to the smaller sample of respondents working in the food and beverage sector, compared to other groups of respondents.

From the research presented in the paper, it can be concluded that during the COVID-19 pandemic, awareness of food safety importance in the Republic of Serbia has increased to some extent, yet it is not in significant correlation to respondents' age. Thus, the research confirmed $\mathrm{H} 1$, that the awareness on food safety during COVID-19 pandemic is not related to age.

The research also indicated that the eating habits of the respondents have not changed drastically. However, changes are noticeable with regard to gender - while men mostly increased intake of fruits/fruit products, women on the other hand increased sweats consumption. Also, greater number of female than male respondents accepted new ways/methods of food preparation due to pandemic. With respect to this, the study did not confirm $\mathrm{H} 2$, that changes in eating habits during the COVID-19 pandemic do not depend on gender.

In conclusion, food sector professionals in the Republic of Serbia have many challenges ahead, as COVID-19 pandemic is still rapidly spreading, and ensuring food safety is highly important not only to hospitality sector, but households and individuals/general population as well.

It is recommended that further research be additionally focused on food safety and its connection to COVID-19, by examining and detecting SARS-CoV-2 on the places where food is produced, stored and delivered, and with aim of keeping food safe for consumption at all times.

\section{Conflict of interests}

The authors declare no conflict of interest. 


\section{Literature}

1. Aarø, L., Zatoński, W., Zatoński, M., \& Wojtyła, A. Declaration from the World Conference on Family Health, Calisia, 2019. Journal of Health Inequalities, 5(2), 129-132.Ahmadiara E. (2020). Possibility of facal-oral transmission of novel coronavirus (SARS-CoV-2) via consumption of contaminated foods of animal origin: a hypothesis. Journal of Food Quality and Hazards Control. 7: 2-3.

2. Al Thani, M.; Al Thani, A.A.; Al-Chetachi, W.; Al Malki, B.; Khalifa, S.A.H.; Bakri, A.H.; Hwalla, N.; Naja, F.; Nasreddine, L. Adherence to the Qatar dietary guidelines: A cross-sectional study of the gaps, determinants and association with cardiometabolic risk amongst adults. BMC Public Health 2018, 18, 503.

3. Associação Brasileira de Nutrologia [Brazilian Association of Clinical Nutrition]. Guide to Healthy Eating in Times of COVID [in Portuguese]. https://www.asbran. org.br/storage/downloads/files/2020/03/guia-alimentar-covid-19.pdf. Published March 2020. (available at: www.asbran.org.br)

4. Ben Hassen, T., El Bilali, H., \& S Allahyari, M. (2020). Impact of COVID-19 on Food Behavior and Consumption in Qatar. Sustainability, 12(17), 6973.

5. Borchgrevink, C. P., Cha, J., \& Kim, S. (2013). Hand washing practices in a college town environment. Journal of environmental health, 75(8), 18-25.

6. Borges do Nascimento, I. J., Cacic, N., Abdulazeem, H. M., von Groote, T. C., Jayarajah, U., Weerasekara, I., et al. (2020). Novel coronavirus infection (covid19) in humans: a scoping review and meta-analysis. J. Clin. Med. 9:941. doi: 10.3390/ jcm9040941

7. Borovčanin, D., \& Kilibarda, N. (2020). Assuring good food handling practices in hospitality, financial costs and employees' attitudes: A case study from Serbia. Scientific journal" Meat Technology”, 61(1), 82-94.

8. Chaloner-Larsson, G., Anderson, R., Egan, A., Da Fonseca Costa Filho, M. A., Gomez Herrera, J. F., \& World Health Organization. (1999). A WHO guide to good manufacturing practice (GMP) requirements (No. WHO/VSQ/97.01). World Health Organization.

9. Chang, L., Yan, Y., \& Wang, L. (2020). Coronavirus disease 2019: coronaviruses and blood safety. Transfusion medicine reviews.

10. Chenarides, L., Grebitus, C., Lusk, J., \& Printezis, I. (2020). Food consumption behavior during the COVID-19 pandemic. Agribusiness.

11. Chodkiewicz, J., Talarowska, M., Miniszewska, J., Nawrocka, N., \& Bilinski, P. (2020). Alcohol consumption reported during the COVID-19 pandemic: The initial stage. International Journal of Environmental Research and Public Health, 17(13), 4677.

12. Di Renzo, L.; Gualtieri, P.; Pivari, F.; Soldati, L.; Attinà, A.; Cinelli, G.; Leggeri, C.; Caparello, G.; Barrea, L.; Scerbo, F.; et al. Eating habits and lifestyle changes during COVID-19 lockdown: An Italian survey. J. Transl. Med. 2020, 18, 229

13. Duda-Chodak, A., Lukasiewicz, M., Zięć, G., Florkiewicz, A., \& FilipiakFlorkiewicz, A. (2020). Covid-19 pandemic and food: Present knowledge, risks, consumers fears and safety. Trends in Food Science \& Technology. 
14. EFSA (2018). The European Union summary report on trends and sources of zoonoses, zoonotic agents and food-borne outbreaks in 2017. EFSA Journal 2018;16(12):5500, 262 pp. https://doi.org/10.2903/j.efsa.2018.5500

15. European Commission. (2004) Regulation (EC) No 852/2004 of the European Parliament and of the Council of 29 April 2004 on the hygiene of foodstuffs

16. FAO. Q\&A: COVID-19 Pandemic-Impact on Food and Agriculture Q1: Will Covid-19 Have Negative Impacts on Global Food Security? FAO: Rome, Italy, 2020.

17. Food and Agriculture Organization of the United Nations [FAO] and World Health Organization [WHO] (2020). COVID-19, And Food Safety. Guidance for Food Businesses. Interim Guidance, April, 1-6. Geneva: WHO

18. Food and coronavirus (COVID-19): what you need to know. European Food Information Council website. https:/www.eufic.org/en/food-safety/article/foodand-coronavirus-covid-19-what-you-need-to-know. Updated March 26, 2020. (available at: www.eufic.org).

19. Gil, M. I., Selma, M. V., López-Gálvez, F., \& Allende, A. (2009). Fresh-cut product sanitation and wash water disinfection: problems and solutions. International journal of food microbiology, 134(1-2), 37-45.

20. Gold, N. A., \& Avva, U. (2018). Alcohol Sanitizer. In StatPearls [Internet]. StatPearls Publishing.

21. Guan, W., Ni, Z., Hu, Y., Liang, W., Ou, C., He, J., et al. (2020). Clinical characteristics of coronavirus disease 2019 in China. N. Engl. J. Med. 382, 1708-1720.

22. Guzek, D., Skolmowska, D., \& Głąbska, D. (2020). Analysis of gender-dependent personal protective behaviors in a national sample: Polish adolescents' COVID-19 experience (PLACE-19) study. International journal of environmental research and public health, 17(16), 5770.

23. Harapan, H., Itoh, N., Yufika, A., Winardi, W., Keam, S., Te, H., et al. (2020). Coronavirus disease 2019 (COVID-19): a literature review. J. Infect. Public Health 13, 667-673.

24. Jay, L. S., Comar, D., \& Govenlock, L. D. (1999). A national Australian food safety telephone survey. Journal of Food Protection, 62(8), 921-928.

25. Jernigan, D.H. America is Drinking Its Way through the Coronavirus Crisis - That Means More Health Woes Ahead. Available online: https://theconversation.com/ america-is-drinking-its-way-ugh-the-coronavirus-crisis-that-means-more-healthwoes-ahead-135532 (available at: theconversation.com).

26. Jin H J, Han D H. 2014. Interaction between message framing and consumers' prior subjective knowledge regarding food safety issues. Food Policy, 44, 95-102.

27. Jingjing Yuan, Yonglong Lu, Xianghui Cao \& Haotian Cui (2020): Regulating wildlife conservation and food safety to prevent human exposure to novel virus, Ecosystem Health and Sustainability, DOI: 10.1080/20964129.2020.1741325

28. Jribi, S.; Ben Ismail, H.; Doggui, D.; Debbabi, H. COVID-19 virus outbreak lockdown: What impacts on household food wastage? Environ. Dev. Sustain. 2020, 22, 3939-3955. 
29. Katri, J.(2020). First respiratory transmitted food borne outbreak? International Journal of Hygiene and Environmental Health

30. Kaul, D. (2020). An overview of coronaviruses including the SARS-2 coronavirus - Molecular biology, epidemiology and clinical implications. Cur. Med. Res. Pract. 10, 54-64. doi: 10.1016/j.cmrp.2020.04.001

31. Kilibarda, N. (2019). Food Safety and Waste in Hospitality. In W. Leal Filho, A. M. Azul, L. Brandli, P. G. Özuyar \& T. Wall (Eds.), Zero Hunger (pp. 1-10). Springer International Pub-lishing. https://doi.org/10.1007/978-3-319-69626-3_107-1

32. Kumar, S., Loughnan, L., Luyendijk, R., Hernandez, O., Weinger, M., Arnold, F., \& Ram, P. K. (2017). Handwashing in 51 countries: analysis of proxy measures of handwashing behavior in multiple indicator cluster surveys and demographic and health surveys, 2010-2013. The American journal of tropical medicine and hygiene, 97(2), 447-459.

33. Lai, C. C., Shih, T. P., Ko, W. C., Tang, H. J., and Hsueh, P. R. (2020). Severe acute respiratory syndrome coronavirus 2 (SARS-CoV-2) and coronavirus disease2019 (COVID-19): the epidemic and the challenges. Int. J. Antimicrob. Agents 55:105924. doi: 10.1016/j.ijantimicag.2020.105924

34. Manning, L. (2018). The value of food safety culture to the hospitality industry. Worldwide Hospitality and Tourism Themes.

35. Micallef, J.V. How The COVID-19 Pandemic is Upending the Alcoholic Beverage Industry. Available online: https://www.forbes.com/sites/joemicallef/2020/04/04/ how-the-covid-19-pandemic-is-upending-the-alcoholic-beverageindustry/\#22cf419d4b0b (available at: www.forbes.com).

36. Milan, B. T,., Jelena, Đ., Snježana, M., Biljana, P., \& Jasna, L. (2013). Potrošači i bezbednost hrane. Hemičara, tehnologa i ekologa, 11-16. [in English: Baltić, M., Đurić, J., Mandić, S., Pećanac, B., Lončina, J., Consumers and food safety. Journal of Chemists, Technologists and Ecologists of the Republic of Srpska, (2013) 11-16].

37. Moynihan, A.B.; van Tilburg, W.A.; Igou, E.R.; Wisman, A.; Donnelly, A.E.; Mulcaire, J.B. Eaten up by boredom: Consuming food to escape awareness of the bored self. Front. Psychol. 2015, 6, 369

38. Naserghandi, A., Allameh, S. F., and Saffarpour, R. (2020). All about COVID-19 in brief. New Microb. New Infect. 35:100678. doi: 10.1016/j.nmni.2020.100678

39. Petrosillo, N., Viceconte, G., Ergonul, O., Ippolito, G., and Petersen, E. (2020). COVID-19, SARS and MERS: are they closely related? Clin. Microbiol. Infect. 26, 729-734. doi: 10.1016/j.cmi.2020.03.026

40. Qiao G H, Guo T, Klein K K. 2012. Melamine and other food safety and health scares in China: Comparing households with and without young children. Food Control, 26, 378-386.

41. Quevedo, R., Bastías, J. M., Espinoza, T., Ronceros, B., Balic, I., \& Muñoz, O. (2020). Inactivation of Coronaviruses in food industry: The use of inorganic and organic disinfectants, ozone, and UV radiation. Scientia Agropecuaria, 11(2), 257-266. 
42. Rossi, E. M., Beilke, L., \& Barreto, J. F. (2018). Microbial contamination and good manufacturing practices in school kitchen. Journal of food safety, 38(1), e12417.

43. Scarmozzino, F.; Visioli, F. Covid-19 and the Subsequent Lockdown Modified Dietary Habits of Almost Half the Population in an Italian Sample. Foods 2020, 9,675 .

44. Serbia (2019). Food Safety Law. Official Gazette of the Republic of Serbia, No. 17/19

45. Shi, M. I. N., XIANG, C., \& ZHANG, X. H. (2020). Impacts of the COVID-19 pandemic on consumers' food safety knowledge and behavior in China. Journal of Integrative Agriculture, 19(12), 2926-2936.

46. Sun, P., Qie, S., Liu, Z., Ren, J., Li, K., and Xi, J. (2020). Clinical characteristics of hospitalized patients with SARS-CoV-2 infection: a single arm meta-analysis. J. Med. Virol. 92, 612-617. doi: 10.1002/jmv.25735

47. The Lancet Infectious Diseases (2020). Challenges of coronavirus disease 2019. Lancet Infect. Dis. 20:261. doi: 10.1016/s1473-3099(20)30072-4

48. Worsfold, D. and C. Griffith: Food safety behavior in the home. British Food Journal, 93(3) (1997) 97-104.

49. www.cdc.gov (available at: https://www.cdc.gov/handwashing/show-me-thescience-handwashing.html

50. www.foodsafety.gov (available at: https://www.foodsafety.gov/keep-food-safe/4steps-to-food-safety)

51. www.gov.uk (available at: https://www.gov.uk/government/news/uk-authorisespfizer-biontech-covid-19-vaccine)

52. www.vet.minpolj.gov.rs (available at: http://www.vet.minpolj.gov.rs/korona/ KORONA - SMERNICE ZA SUBJEKTE U POSLOVANJU HRANOM.pdf)

53. www.who.int (available at: https://emergencies/diseases/novel-coronavirus-2019/ advice-for-public)

54. Y1lmaz, C.; Gökmen, V. Neuroactive compounds in foods: Occurrence, mechanism and potential health effects. Food Res. Int. 2020, 128, 108744. 